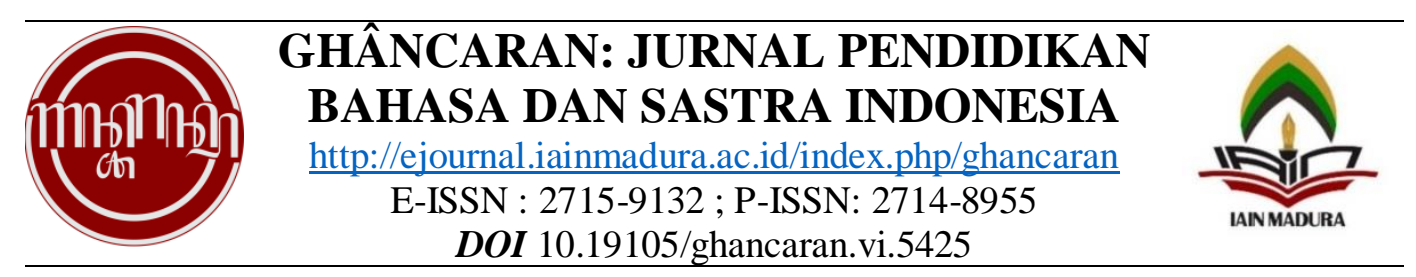

\title{
Pendidikan Karakter Siswa Melalui Pembelajaran Bahasa Indonesia di Pasca Pandemi pada Madrasah Aliyah An-Najah I Karduluk, Sumenep
}

\author{
Albaburrahim* \\ *Tadris Bahasa Indonesia, IAIN Madura \\ Alamat surel: albaburrahim@iainmadura.ac.id
}

\begin{tabular}{ll}
\hline & Abstract: \\
\hline Keywords: & Education does not only require students to have knowledge \\
Character & and skills. Education also aims to shape the character of \\
Building; & students so that they have strong, critical, and moral \\
Indonesian & personalities according to the noble values of the Indonesian \\
Language & nation. Character education can be done through various \\
Learning; & lessons in class, one of which is Indonesian learning. \\
Pont & Indonesian language learning has a great opportunity to \\
& encourage students to have characters that are in \\
& accordance with the personality values of the Indonesian \\
& nation, especially in facing a pandemic. This study aims to \\
& determine the role of Indonesian language learning in \\
& instilling character education values. This study used \\
& descriptive qualitative method. Data collection techniques \\
& through documentation and observation. The analysis \\
& technique is in the form of data analysis and observation of \\
& the research object. The results of this study indicate that \\
& character education through learning Indonesian there are \\
& several personality values obtained by students, namely 1) \\
& the value of honesty, 2) the value of discipline, 3) the value of \\
& responsibility, 4) the value of tolerance.
\end{tabular}

\section{Abstrak:}

Kata Kunci:

Pendidikan

Karakter;

Pembelajaran

Bahasa Indonesia;

Pasca Pandemi.
Pendidikan bukan hanya menuntut siswa untuk memiliki pengetahuan dan keterampilan. Pendidikan juga bertujuan membentuk karakter siswa agar memiliki kepribadian tangguh, kritis, dan bermoral sesuai nilai-nilai luhur yang dimiliki bangsa Indonesia. Pendidikan karakter dapat dilakukan melalui berbagai pelajaran di kelas, salah satunya pembelajaran Indonesia. Pembelajaran bahasa Indonesia berpeluang besar untuk mendorong siswa memiliki karakter yang sesuai dengan nilai-nila kepribadian bangsa Indonesia, terutama dalam menghadapi pandemi. Penelitian ini bertujuan untuk mengetahui peran pembelajaran bahasa Indonesia dalam menanamkan nilai-nilai pendidikan karakter. Penelitian ini menggunakan metode deskriptif kualitatif. Teknik pengumpulan data melalui dokumentasi dan observasi. Teknik analisis berupa analisis data dan pengamatan terhadap obyek penelitian. Hasil penelitian ini menunjukkan bahwa Pendidikan karakter melalui pembelajaran bahasa Indonesia terdapat beberapa nilai-nilai 
kepribadian yang diperoleh siswa, yaitu 1) nilai kejujuran, 2)

nilai disiplin, 3) nilai bertanggung jawab, 4) nilai toleransi.

\begin{tabular}{ccc} 
Terkirim: 13-09-2021 & ; Revisi: 05-10-2021 & ; Diterima: 28-10-2021 \\
\hline OGhâncaran: Jurnal Pendidikan Bahasa dan Sastra Indonesia \\
Tadris Bahasa Indonesia \\
Institut Agama Islam Negeri Madura, Indonesia
\end{tabular}

\section{PENDAHULUAN}

Pendidikan salah satu hal yang tak dapat dipisahkan dalam kehidupan manusia. Bahkan, Pendidikan sudah mulai dari manusia lahir hingga kembali kepada Sang Pencipta. Melalui Pendidikan, manusia bisa meningkatkan kualitas ilmu pengetahuan dan keterampilannya. Semakin tinggi tingkat pendidikan seseorang, maka akan semakin tinggi pula kualitas kemampuannya (Irsyad, 2021). Bahkan, dalam menghadapi era digital yang semakin berkembang setiap saat, sehingga membutuhkan keahlian dan keterampilan tertentu dalam menghadapinya. Apalagi saat ini pandemi covid 19 masih terasa dalam pendidikan dan pembelajaran di sekolah.

Menyoal pendidikan, tentu salah satu isu utama dalam pendidikan yaitu tentang pendidikan karakter. Oleh karena itu, pendidikan karakter menjadi salah satu hal penting dalam proses pembentukan nilai, moral dan akhlak generasi bangsa. Pendidikan karkater tentu harus menjadi landasan utama yang kokoh dalam mewujudkan generasi bangsa yang bermartabat. Adanya pendidikan karakter keberadaan sumber daya alam Indonesia yang melimpah mampu dikelolal secara profesional oleh sumber daya manusia yang cerdas dan bermoral yang nantinya mampu menyeimbangkan kebutuhan manusia dengan lingkungan alam (Fitri, Sofia Ratna Awaliyah;Tantowiye, 2016). Pembentukan karakter tentu terasa berat ditanamkan kepada siswa, jika pembelajaran di kelas tidak memiliki terobosan pasca pandemi covid 19 yang masih tidak menentu kondisinya setiap waktu.

Pendidikan karakter sendiri menurut Suprapto yaitu sebuah usaha yang dilakukan dalam mengembangkan karakter yang baik (good character) dengan landasan nilai-nilai kebajikan (core virtues) secara objektif dalam individu ataupun masyarakat (Deliani, Sulistiyawati, \& Sahril, 2018). Artinya, Pendidikan karakter harus dilakukan secara terencana dan terstruktur dalam membentuk kepribadian yang baik. Tanpa adanya rencana yang terstruktur, maka pendidikan karakter akan sulit terealisasi dalam dunia pendidikan. Karena pada dasarnya pendidikan harus mengupayakan pengembangan yang komprehensif baik dalam keterampilan maupun nilai atau moral.

Pembentukan karakter tentunya tidak mungkin secara langusng terbentuk dalam sebuah pendidikan. Menurut (Rezki, Salam, \& Saleh, 2021) bahwa pembentukan 
karakter bukan dibentuk oleh orang tua saja, melainkan guru harus memberikan contoh dan tauladan baik bagi siswanya. Hal ini menunjukan peran sentral guru dalam proses pembelajaran menjadi penting dalam pembentukan karakter siswa. Ketauladanan dan contoh bisa menjadi hal utaama. Selain itu, guru juga harus mampu menyampaikan pelajaran secara baik dengan menghubungkan nilai-nilai pendidikan karakter siswa dalam materi ajarnya (Pratiwi, Rohmadi, \& Anindyarini, 2017).

Bahasa Indonesia merupakan salah satu pelajaran wajib, tentu menjadi bagian penting dalam pembentukan karakter bagi siswa (Wardani, Andayhani, \& Suyhitno, 2019). Setidaknya pendidikan karakter dalam pembelajaran bahasa Indonesia mengikuti fungsi pokok bahasa itu sendiri. Pertama, alat komunikasi yaitu bahasa Indonesia sebagai alat komunikasi siswa dalam berinteraksi dengan lingkungannya. Kedua, edukatif yaitu siswa mampu mendapatkan nilai-nilai dalam pembentukan karakter dan identitas bangsa. Ketiga, kultural yaitu siswa mampu menggali dan menanamkan nilai-nilai yang terdapat dalam budaya Indonesia, sehingga mampu membangun identitas bangsa (Siregar, 2019).

Pendidikan karakter melalui pembelajaran bahasa Indonesia memiliki beberapa tujuan, yaitu sebagai berikut. (1) siswa mampu mengembangkan potensi yang dapat disesuaikan dengan kebutuhan, kemampuan dan minatnya. Bahkan mampu menumbuhkan hasil dari karya sastra dan intelektual dari bangsa sendiri. (2) Pengembangan kompetensi bahasa yang dilakukan oleh pendidik terhadap siswa dalam menyediakan kegiatan berbahasa, bersastra dan sumber belajar. (2) Penentuan bahan ajar dalam kebahasaan dan kesastraan dapat dilakukan secara mandiri dan leluasa oleh pendidik, sehingga mampu menyesesuaikan dengan lingkungan sekolah dan kemampuan siswa (Nugrahani, 2017). Berdasarkan tujuan tersebut, maka pembelajaran bahasa Indonesia mampu memberikan peluang besar dalam menanamkan pendidikan karakter terhadap sisiwa di madrasah aliyah, terutama pasca pandemi covid 19.

Sistem pembelajaran di masa pandemi memang harus dilakukan secara jarak jauh. Walaupun demikian, sebenarnya pembelajaran jarak jauh bukan suatu hal yang baru dalam dunia pendidikan Indonesia. Hal ini sudah banyak lembaga pendidikan baik formal ataupun non formal telah melaksanakan pembelajaran jarak jauh (Ummah, 2020). Namun, masa pasca pandemi covid 19 saat ini pembelajaran mulai dilakukan pembelajaran tatap muka secara terbatas. Hal ini memberikan harapan besar kepada dunia pendidikan, terutama pembelajaran bahasa Indonesia untuk melanjutkan penanaman pendidikan kaarakter kepada siswa yang telah lama melaksanakan 
pembelajaran jarak jauh. Salah satunya di Madrasah Aliyah An-Najah I Karduluk, Sumenep suatu lembaga pendidikan Islam yang berbasis pesantren di Madura.

Pendidikan karakter melalui pembelajaran bahasa Indonesia pernah dilakukan penelitian oleh beberapa peneliti. Adapun penelitian tersebut pernah dilakukan (Siregar, 2019) yang meneliti tentang "Pengintegrasian Pendidikan Karakter dalam Pembelajaran Bahasa Indonesia”. Penelitian ini dilatarbelakangi dari anggapan bahwa bahasa Indonesia merupakan suatu sumber pendidikan karakter yang tidak diragunakan. Hal ini dikarenakan bahasa Indonesia memiliki substansi utama dalam nilai-nilai pendidikan karakter. Adapun hasil penelitian dapat menyimpulkan bahwa pembelajaran bahasa Indonesia diharapkan dapat berlangung pada setiap kompetensi dasar dan indikator dari hasil pembelajaran untuk mencapai pendidikan karakter.

Penelitian lain yaitu tentang "Pendidikan Karakter Siswa melalui Pembelajaran Bahasa Indonesia" yang menghasilkan kesimpulan bahwa pembelajaran bahasa Indonesia harus mengunadkan sistem pembelajaran dengan pendekatan dari guru atau pendidik. Sehingga, pembelajaran bahasa Indonesia dapat berperan aktif dalam meningkatkan kemampuan berbahasa siswa yang dapat menggambarkan karakter pribadi seseorang (Putri, 2020). Selain itu, penelitian tentang pendidikan karakter juga pernah dilakukan oleh (Rezki et al., 2021) dengan judul "Integrasi Pendidikan Karakter pada Pembelajaran Bahasa Indonesia". Penelitian ini menemukan beberapa kesimpulan, yaitu (1) Pembelajaran bahasa Indonesia dapat mengintegrasikan pendidikan karakter yang terdapat pada silabus dan RPP yang berisi tentang nilai-nilai pendidikan karakter. (2) Implementasi pendidikan karakter pada pembelajaran bahasa Indonesia harus melalui tahapan, seperti tahapan perencanaan, pelaksanaan dan evaluasi. (3) Adapun hambatan terjadi dalam implementasinya yaitu terdapat pada faktor internal.

Adapun penelitian ini dilakukan di Madrasah Aliyah An-Najah I Karduluk, Sumenep yang merupakan suatu Lembaga Pendidikan Islam (LPI) yang terdapat di lingkungan pesantren di Madura. Bahasa Indonesia di Madrasah Aliyah ini merupakan salah satu mata pelajaran yang wajib ada. Sehingga, hal ini menjadi suatu peluang untuk mengimplementasikan nilai-nilai pendidikan karakter melalui pembelajaran bahasa Indonesia. Bahkan, Pendidikan karakter di lingkungan pesantren merupakan suatu nilai-nilai yang selalu ditanamkan kepada siswa atau santrinya sebagai ciri khas pesantren. Bahkan, pendidikan di sekolah ini juga merasakan dampak dari pandemi covid 19. Berdasarkan penjelasan di atas, maka peneliti merasa tertarik untuk melakukan suatu penelitian dengan judul "Pendidikan Karakter Siswa melalui 
Pembelajaran Bahasa Indonesia di Pasca Pandemi pada Madrasah Aliyah An-Najah I Karduluk, Sumenep".

\section{METODE}

Berdasarkan judul penelitian ini, yaitu "Pendidikan Karakter Siswa melalui Pembelajaran Bahasa Indonesia di Pasca Pandemi pada Madrasah Aliyah An-Najah I Karduluk, Sumenep", maka pendekatan yang dilakukan pada penelitian ini adalah metode penelitian deskriptif kualitatif. Penelitian ini mengkaji tentang penanaman nilainilai pendidikan karakter melalui pembelajaran bahasa Indonesia, khususnya pasca pandemi covid 19 yang dilakukan pada Madrasah Aliyah. Teknik pengumpulan data yaitu berupa wawancara, observasi dan dokumentasi agar peneliti memperoleh data dan informasi yang valid. Adapun Langkah-langkahnya, yaitu: pertama, melakukan wawancara kepada pihak terkait, seperti kepala madrasah, guru dan siswa. Kedua, melakukan pengamatan di kelas saat pembelajaran bahasa Indonesia. Ketiga, melakukan membaca silabus, RPP dan materi pelajaran bahasa Indonesia kelas $\mathrm{X}$ yang berkaitan dengan pendidikan karakter. Penelitian ini dianalisis dengan reduksi data, penyajian data dan penarikan kesimpulan.

\section{HASIL DAN PEMBAHASaAN}

Hasil yang terdapat dalam penelitian ini berupa penerapan nilai-nilai pendidikan karakter melalui materi-materi pembelajaran bahasa Indonesia di kelas $\mathrm{X}$ pada madrasah Aliyah An-Najah I Karduluk, Sumenep. Adapun materi-materi pada pelajaran bahasa Indonesia, yaitu seperti teks laporan hasil observasi, teks eksposisi, teks anekdot, membuat kesepakatan hasil negosiasi, berpendapat melalui debat dan mendalami puisi. Sedangkan, nilai-nilai pendidikan karakter yang dapat diterapkan dalam pembelajaran bahasa Indonesia, yaitu nilai kejujuran, nilai kedisiplinan, nilai bertanggung jawab, nilai toleransi.

\section{Pembelajaran Bahasa Indonesia di Madrasah Aliyah}

Salah satu fungsi bahasa Indonesia adalah sebagai alat komunikasi yang efektif bagi masyarakat Indonesia. Selain itu, bahasa Indonesia juga memiliki fungsi sebagai salah satu alat pemersatu bangsa tentu harus digunakan dalam dunia pendidikan sebagai penanaman identitas bangsa (Siregar, 2019). Maka dari itu, pembelajaran bahasa Indonesia yang terdapat dalam pendidikan harus terus dilestarikan dan dikembangkan, agar siswa sebagai generasi Indonesia di masa datang mampu menggunakan bahasa Indonesia dengan baik, benar dan santun untuk dapat 
mencerminkan sebagai masyarakat Indonesia yang ramah, santun dan berbudi luhur dalam berbahasa.

Pembelajaran bahasa Indonesia secara hakikat sebagai bahasa pengantar bagi peserta didik dalam terampil berbahasa dan berkomunikasi. Hal ini tercermin dari empat aspek keterampilan berbahasa, yaitu keterampilan menyimak, berbicara, membaca dan menulis (Siregar, 2019). Walaupun demikian, keterampilan berbahasa tersebut dapat dibagi menjadi beberapa materi yang disesuaikan dengan Kompetensi Inti (KI) dan Kompetensi Dasar (KD) dalam kurikulum 2013 yang disempurnakan.

Adapun beberapa materi yang terdapat dalam pembelajaran Bahasa Indonesia untuk kelas X di Madrasah Aliyah An-Najah I Karduluk, Sumenep yaitu sebagai berikut:

\section{a. Teks Laporan Hasil Observasi}

Teks laporan observasi adalah bagiaan dari materi yang ada dalam pelajaran bahasa Indonesia pada semester I. Teks laporan hasil observasi merupakan suatu karangan yang memaparkan kegiatan dalam suatu pengamatan., penelitian, survey, riset dan kunjungan terhadap suatu objek. Teks ini memberikan informasi terhadap sesuatu hal, berdasarkan suatu fakta dari pengamatan secara langsung. Adapun sifat dari teks laporan hasil observasi harus bersifat informatif, komunikatif dan objektif. Sebab teks ini ditulis harus berdasarkan fakta yang sesungguhnya tanpa suatu rekayasa yang dibuat oleh penulis. Sedangkan fungsi dari teks laporan hasil observasi yaitu bertujuan memberi tahu secara jelas dari hasil pengamatan untuk memberikan informasi kepada pihak yang berwenang dalam berbagai kepentingan.

Adapun ciri dari teks laporan hasil observasi, yaitu:

1. Pengamatan harus bersifat objektif dan tidak memihak kepada pihak tertentu.

2. Penulisan teks laporan didasari oleh fakta yang terjadi saat pengamatan.

3. Laporan tidak boleh bersifat menyimpang dengan melakukan dugaan serta pemihakan terhadap salah satu pihak tertentu.

4. Penulisan harus lengkap dan sempurna

5. Teks laporan observasi harus bersifat universal dan global.

Sedangkan dalam teks laporan hasil observasi terdapat berbagai struktur, seperti:

1. Pernyataan umum (klasifikasi) yang berisi tentang bagian pembuka atau pengantar dalam suatu teks laporan.

2. Deskripsi bagian yaitu tentang penjelasan secara rinci mengenai objek dan bagian-bagiannya. 
3. Deskripsi manfaat menjelaskan manfaat ataupun fungsi objek yang telah diamati (Kurniawan et al., 2021).

\section{b. Teks Eksposisi}

Setiap orang pasti akan pernah menyampaikan pendapat tentang sesuatu hal, termasuk untuk menanggapi permasalahan yang terjadi. Menyampaikan pendapat bisa dilakukan secara lisan ataupun tertulis. Secara lisan artinya seseorang menyampaikan pendapat secara langsung, sedangkan secara tertulis artinya seseorang menyampaikan pendapat dengan menggunakan tulisan. Adapun menyampaikan pendapat secara tulisan dapat disebutkan sebagai teks eksposisi.

Teks eksposisi suatu teks yang berisi tentang gagasan, pendapat ataupun opini dengan maksud menanggapi atau menyikapi suatu permasalahan yang sedang berkembang saat itu. Teks eksposisi biasanya digunakan dalam bentuk gagasan seseorang. Adapun gagasan tersebut nantinya akan dikaji atau ditanggapi oleh penulis dengan sudut pandang tertentu. Sedangkan gagasan yang disampaikan tentu harus menyertakan argumen yang logis secara bertanggung jawab. Teks eksposisi sendiri bertujuan memperjelas pemahaman masyarakat tentang suatu persoalan yang perlu dicermati dan direspon dengan menawarkan solusi dalam menyelesaikan permasalahan.

Adapun ciri-ciri dalam teks eksposisi, yaitu:

1. Menggunakan gaya informasi persuasi yang berisi ajakan.

2. Tidak memaksakan kemauan penulis serta tidak memihak kepada pihak tertentu.

3. Menjelaskan informasi atau permasalahan yang sedang terjadi.

4. Menyampaikan pendapat berdasarkan fakta sebagai bentuk pembuktian.

5. Menggunakan opini dalam menyatakan sikap terhadap persoalan yang ditanggapi (Kurniawan et al., 2021).

\section{c. Membuat Kesepakatan Hasil Negosiasi}

Setiap manusia sering kali melakukan tawar menawar dengan orang lain di berbagai bidang, seperti halnya dalam jual beli, pengusaha maupun yang lainnya. Negosiasi dapat juga disebut proses tawar menawar dari kedua belah pihak untuk menghasilkan kesepakatan tertentu. Proses awar menawar dalam bentuk negosiasi bukan hanya dilakukan saat proses jual beli yang sering kita lihat. Namun, dalam kehidupan sehari-hari kita juga melakukan proses negosiasi selain dari kegiatan jual beli. 
Negosiasi itu sendiri merupakan bentuk interaksi sosial yang memiliki fungsi menyelesaikan berbagai permasalahan dari pihak-pihak yang berkepentingan. Adapun pihak tersebut dapat berusaha menyelesaikan perbedaan dengan cara baik melaui negosiasi yang dapat menghasilkan kesepakatan. Sehingga, kedua belah pihak dapat menyetujui dan menerima dari kesepakan yang telah ditetapkan.

Sedangkan ciri teks negosiasi, yaitu:

1. Adanya kesepakatan dari kedua belah pihak yang berkepentingan.

2. Mengarah kepada tujuan praktis dalam kehidupan sehari-hari.

3. Hasil kesepakatan dapat memprioritaskan kepentingan bersama, bukan salah satu pihak tertentu.

4. Sebagai sarana dalam mencari pemecahan dalam berbagai permasalahan.

Adapun manfaat yang dapat diperoleh dalam melakukan negosiasi yaitu mampu melatih sebuah kemampuan kepada sesorang yang bersosialisasi dengan masyarakat. Negosiasi yang dilakukan mampu menyampaikan pendapat dan gagasan dengan baik serta mampu mempertahankannya. Namun, kemampuan negosiasi harus terus diasah secara terus menerus agar memiliki kecapakan dan kesantunan dalam menyampaikan dan mempertahankan gagasan kitia. Maka dari itu, kemampuan ini sangat penting dimiliki sesorang untuk bisa memecahkan persoalan yang belum terselesaikan (Kurniawan et al., 2021).

\section{Pendidikan Karakter dalam Pembelajaran Bahasa Indonesia di Madrasah Aliyah}

Sejak lama pendidikan karakter didengungkan dalam pendidikan di Indonesia. Pendidikan karakter sendiri maknanya lebih tinggi dibandingkan pendidikan moral. Hal ini berdasarkan dari pembahasan pendidikan karakter yang bukan hanya tentang benar dan salah, melainkan lebih kepada pembiasaan dalam kehidupan sehari-hari untuk melakukan hal yang baik, sehingga nantinya siswa akan memiliki karakter yang secara sadar dan paham untuk berkomitmen pada nilai-nilai baik dalam kehidupan sehari-hari (Putri, 2020). Pendidikan karakter sebenarnya merupakan suatu proses dalam memberikan tuntunan terhadap siswa agar mampu menjadi manusia yang seutuhnya dengan memiliki karakter dari dimensi hati, pikiran, raga, rasa dan karsa. Bahkan nantinya, karakter tersebut akan tercermin keselarasan dan keharmonisan dalam kepribadian utuh dalam olah hati, pikiran, rasa dan karsa (Julaiha, 2021). Maka dari itu, pendidikan karakter harus mampu mengubah siswa menjadi manusia yang seutuhnya dengan memiliki kepribadian dan berkarakter sesuai dengan nilai-nilai luhur. 
Berdasarkan Publikasi Pusat Kurikulum pendidikan karakter sendiri terdapat beberapa fungsi, yaitu (1) sebagai pengembangan potensi dasar yang nantinya akan berpotensi secara baik dengan berperilaku baik; (2) Sebagai penguatan dalam pembangunan sikap dan perilaku bangsa yang multi budaya; (3) sebagai peningkatan peradaban bangsa yang semakin kompetitif di era global. Sedangkan nilai-nilai karakter yang dapat dibentuk dalam pendidikan karakter dapat diidentifikasikan sebagai berikut, yaitu: (1) Religius, (2) Toleransi, (3) Jujur, (4) Mandiri, (5) Kreatif, (6) Kerja keras (7) Jujur, (8) Rasa Ingin Tahu, (9) Demokratis; (10) Cinta Tanah Air (11) Semangat Kebangsaan, (12) Peduli Sosial, (13) Peduli Lingkungan, (14) Cinta Dama, (15) Tanggung Jawab, (16) Bersahabat/Komunikatif, (17) Menghargai Prestasi dan (18) Gemar Membaca (Putri, 2020).

Pendidikan karakter akan tercapai di sekolah tentu wajib melibatkan semua komponen (stakeholders) dalam proses pembelajaran serta penilaian di kelas, kualitas hubungan siswa dan guru, penanganan dan pengelolaan mata pelajaran oleh waka kurikulum, pengelola sekolah (kepala sekolah), kegiatan dan aktivitas ekstra kurikuler, sarana dan prasarana yang memadai, pembiayaan dan etos kerja (Siregar, 2019). Oleh karena itu, peran serta dari setiap komponen harus saling bersinergi satu sama lain. Sebab pendidikan karakter tidak akan tercapai apabila komponen tersebut saling tumpang tindih dan tidak berkesinambungan. Sepertihalnya pembelajaran dalam kelas harus bisa bersinergi dengan guru di kelas.

Salah satu pelajaran wajib yang ada di setiap jenjang pendidikan termasuk Madrasah Aliyah An-Najah I Karduluk Sumenep yaitu bahasa Indonesia. Pelajaran ini tentu sangat memiliki keterkaitan dalam pendidikan karakter. Pembelajaran bahasa Indonesia sendiri dapat berproses secara langsung ataupun tidak langsung dalam dalam pendidikan karakter. Hal ini bisa dikaitkan dengan tuturan yang berkenaan dengan komunikasi yang bisa mengetahui karakter atau kepribadian seseorang. Komunikasi yang digunakan dalam bahasa Indonesia akan dilihat dari cara berbahasa secara baik, teratur dan mudah dipahami oleh orang lain (Sulistiyowati, 2013). Hal ini menunjukan bahwa identitas dan jati diri bangsa salah satu fungsi bahasa Indonesia.

Pembelajaran bahasa Indonesia di Madrasah Aliyah An-Najah I Karduluk Sumenep tentu tidak terlepas dari keterampilan membaca, menulis, menyimak dan berbicara dengan penggunaan bahasa Indonesia yang baik dan benar. Maka keterampilan tersebut tentu memengaruhi karakter dari siswa. Bahkan, pembelajaran bahasa Indonesia juga membahas sastra Indonesia yang dapat diilhami oleh siswa dalam menanamkan kepribadian sesuai nillai-nilai luhur bangsa Indonesia (Manurung \& 
Siregar, 2017). Sedangkan nilai-nilai karakter dalam pembelajaran bahasa Indonesia yang ada di Madrasah Aliyah An-Najah I Karduluk Sumenep, yaitu:

1. Jujur

Jujur merupakan sikap dan perilaku yang menggambarkan suatu kesatuan dalam pengetahuan, perkataan dan perbuatan, sehingga seseorang dapat menjadi orang yang dipercaya (Kemdikbud, 2019). Pada pembelajaran bahasa Indonesia nilai kejujuran dapat diterapkan dan ditanamkan pada materi teks laporan hasil observasi. Guru mampu memberikan pemahaman kepada siswa bahwa dalam melakukan pengamatan harus bersikap jujur dan tidak boleh ada manipulasi dari hasil observasi tersebut.

2. Disiplin

Disiplin salah satu nilai karakter yang berkaitan dengan kebiasaan dan perbuatan secara konsisten dalam aturan atau tata tertib yang berlaku (Kemdikbud, 2019). Sedangkan dalam pembelajaran bahasa Indonesia dapat menanamkan nilai disiplin dengan materi debat. Setiap pelaksanaan debat itu pasti ada aturan yang telah ditentukan oleh moderator atau panelis. Sehingga peserta debat harus disiplin mengikuti aturan dan tata tertib yang telah ditetapkan.

3. Bertanggung Jawab

Nilai karakter ini adalah salah satu sikap dan perilaku yang harus dilakukan seseorang dalam melaksanakan tugas dan kewajiban yang telah menjadi beban baik kepada agama, sosial, masyarakat, bangsa dan negara (Kemdikbud, 2019). Salah satu materi yang dapat menanamkan nilai karakter tanggung jawab adalah teks anekdot. Sebab teks ini walaupun merupakat teks yang sifatnya menghibur, namun di dalam teks anekdot ada pesan moral yang harus disampaikan secara bertanggung jawab.

4. Toleransi

Karakter ini adalah sebuah sikap dan perilaku yang menghargai setiap perbedaan agama, aliran kepercayaan, suku, adat, bahasa, ras, etnis dan pendapat (Kemdikbud, 2019). Pada karakter ini guru bisa menanamkan nilai karakter kepada siswa dengan materi cerita rakyat (hikayat) dan debat. Materi hikayat merupakan cerita rakyat yang diwariskan secara turun temurun dari berbagai daerah yang berbeda-beda. Sehingga, siswa bisa menghargai hikayat yang berbeda-beda di setiap daerah. Sedangkan materi debat tentu berkaitan dengan menghargai perbedaan pendapat dengan orang lain. 
Kunci pendidikan karakter sebenarnya terdapat pada budaya di kelas, budaya di sekolah dan budaya di keluarga atau masyarakat (Kusnoto, 2017). Namun, pembelajaran bahasa Indonesia di Madrasah Aliyah salah satu bagian kunci untuk menyukseskan nilai-nilai pendidikan karakter bagi siswa. Setiap materi pembelajaran bahasa Indonesia mampu dikaitkan secara bersamaan dengan nilai-nilai pendidikan karakter yang telah ditetapkan. Sehingga, bahasa Indonesia bukan hanya sebagai alat pemersatu bangsa, melainkan mampu menanamkan jati diri dan karakter bangsa yang sesuai nilai budaya Indonesia.

\section{SIMPULAN}

Bahasa merupakan sebagai salah satu wahana dalam pendidikan karakter, sehingga harus direncanakan, dibina, dan dikembangkan dalam menanamkan nilai-nilai karakter. Pembelajaran bahasa Indonesia sebagai bentuk pengenalan nilai-nilai karakter dalam setiap materi bahasa Indonesia, seperti debat dengan indah, teks anekdot, teks eksposisi, hikayat dan lain sebagainya. Peran guru sangat penting dalam mengintegrasikan pembelajaran bahasa Indonesia dengan pendidikan karakter. Sebab bahasa Indonesia sebagai mata pelajaran wajib di setiap tingkat pendidikan menjadi peluang untuk memasukan pendidikan karakter kepada siswa, terutama di masa pasca pandemi. Pendidikan karakater yang terdapat dalam pembelajaran bahasa Indonesia di Madrasah Aliyah An-Najah I Karduluk Sumenep, salah satunya adalah sikap jujur, disiplin, bertanggung jawab dan toleransi. Karakter ini diharapkan mampu menyiapkan siswa untuk menghadapi tantangan pasca pandemi covid 19.

\section{DAFTAR RUJUKAN}

Deliani, S., Sulistiyawati, S., \& Sahril. (2018). PENDIDIKAN KARAKTER MELALUI PEMBELAJARAN BERBASIS LITERASI PADA MAHASISWA PPS PENDIDIKAN BAHASA INDONESIA UMN AL WASHLIYAH (Character Education Through Literacy-Based Learning in Students PPS Pendidikan Bahasa Indonesia UMN AI Washliyah). Edulitera, 1-7. Medan: Edulitera.

Fitri, Sofia Ratna Awaliyah;Tantowiye, T. A. (2016). Nilai-Nilai Pendidikan Karakter Dalam Al-Qur'an Surah Al-An'am Ayat 151-153 dan Implementasinya Dalam Pembelajaran Pendidikan Agama Islam (Studi Analisis Terhadap Tafsir Al-Munir Karya Wahbah Az-Zuhaili). Tarbiyah Al Aulad, 1(1), 82-98. Retrieved from https://riset-iaid.net/index.php/TA/article/view/100

Irsyad, N. A. (2021). Implementasi Pendidikan Karakter dalam Pembelajaran Bahasa Indonesia pada Siswa Kelas VIII UPT SPF SMP Negeri 53 Makassar. Universitas Muhammadiyah Makassar.

Julaiha, S. (2021). IMPLEMENTASI PENDIDIKAN KARAKTER DALAM PEMBELAJARAN. DINAMIKA ILMU: Jurnal of Education, 14(2), 226-239. 
https://doi.org/https://doi.org/10.21093/di.v14i2.15

Kemdikbud. (2019). Kajian dan Pedoman Penguatan Pendidikan Karakter (PPK). Kementrian Pendidikan Dan Kebudayaan Republik Indonesia, 1-90. Retrieved from https://cerdasberkarakter.kemdikbud.go.id/?wpdmpro=buku-konsep-danpedoman-ppk

Kurniawan, B., Kirana, C., Setya, C., Purwanti, E., Puspitawati, E., Wulandari, F., \& Pradmudyanti, I. R. (2021). Belajar Praktis Bahasa Indonesia. Klaten: Viva Pakarindo.

Kusnoto, Y. (2017). INTERNALISASI NILAI-NILAI PENDIDIKAN KARAKTER PADA SATUAN PENDIDIKAN. $4(2)$,

247-256.

https://doi.org/http://dx.doi.org/10.31571/sosial.v4i2.675

Manurung, A. S., \& Siregar, J. (2017). Melalui Pembelajaran Bahasa Dan Sastra. Prosiding Seminar Nasional Bahasa Dan Sastra Indonesia Dalam Konteks Global, 705-714.

Nugrahani, F. (2017). Pendidikan Karakter Melalui Pembelajaran Bahasa Indonesia. Jurnal Edudikara, 2(2), 113-124.

Pratiwi, T., Rohmadi, M., \& Anindyarini, A. (2017). IMPLEMENTASI PENDIDIKAN KARAKTER DALAM PEMBELAJARAN MENULIS PUISI ( STUDI KASUS SISWA KELAS VII SMP NEGERI 16 SURAKARTA ) Tia Pratiwi, Muhammad Rohmadi, Atikah Anindyarini Universitas Sebelas Maret Surakarta Surel: tiapratiwi96@gmail.com Bangsa Indones. Basastra, 5(3), 199-206. https://doi.org/https://jurnal.fkip.uns.ac.id/index.php/bhs_indonesia/article/view/1158 $7 / 8291$

Putri, F. N. (2020). Pendidikan Karakter Siswa Melalui Pembelajaran Bahasa Indonesia. Jurnal Pendidikan Bahasa Indonesia., 8(1), 16-24.

Rezki, N., Salam, S., \& Saleh, M. (2021). Integrasi Pendidikan Karakter Pada Pembelajaran Bahasa Indonesia. SOCIETIES: Journal of Social Science and Humanities, $1(2)$,

144-150.

https://doi.org/https://doi.org/10.26858/societies.v1i2.21930

Siregar, R. (2019). Pengintegrasian Pendidikan Karakter Dalam. 8(1), 1-10.

Sulistiyowati, E. (2013). PENDIDIKAN KARAKTER DALAM PEMBELAJARAN BAHASA INDONESIA. Edukasia: Jurnal Penelitian Pendidikan Islam, 8(2), 311-330. https://doi.org/10.21043/edukasia.v8i2.756

Ummah, L. F. (2020). Integrasi Pendidikan Karakter Dalam Pembelajaran Jarak Jauh Bahasa Dan Sastra Indonesia. Jurnal Edukasi Khatulistiwa, 3(2), 85. https://doi.org/10.26418/ekha.v3i2.41259

Wardani, S. R., Andayhani, A., \& Suyhitno, S. (2019). Pentingnya Pendidikan Karakter dalam Pembelajaran Bahasa Indonesia. Prosiding Seminar Nasional "Inovasi Pembelajaran Bahasa Indonesia Di Era Revolusi Industri 4.0," 33-36. Surakarta: Universitas Sebelas Maret Surakarta. 